http://dx.doi.org/10.4314/jae.v17i1.18

\title{
Soil conservation practices among Arable Crop Farmers In Enugu - North Agricultural Zone, Nigeria: Implications for Climate Change
}

\author{
${ }^{1}$ Dimelu, M. U*; ${ }^{2}$ Ogbonna, S. E.. and ${ }^{3}$ Enwelu, I. A \\ Department of Agricultural Extension \\ University of Nigeria, Nsukka \\ Enugu State. \\ E-mails:1'mabeldimelu@yahoo.com; \\ 08185631828
}

\begin{abstract}
The study examined soil conservation practices used by arable crop farmers in Enugu - North agricultural zone of Enugu State. One hundred and twenty randomly selected arable crop farmers were interviewed. Data were analysed by use of percentage and mean score. The study revealed that respondents used organic manure (87.5\%), planting of cover crops (87.5\%), crop rotation (86.7\%), mulching (85.8\%), inorganic manure (76.7\%), contour bonds(75.8\%), liming (61.7\%), and terracing $(60.8 \%)$ for soil conservation in the zone. However, organic manure $(M=$ 3.32), use of inorganic manure $(M=3.08)$, crop rotation $(M=2.86)$, and mulching ( $M=2.82$ ) were most preferred by the respondents The major reasons indicated for use of most soil conservation practices included enhanced productivity, high quality products, long term nutrient value and others. While most of the preferred conservation practices hold great potential for increased production, income for farmers and enhanced food security for the nation, some are implicated as causes of climate change. The more environment friendly and climate change sensitive practices are less popular among the farmers. The paper recommends concerted efforts to promote among farmers the conservation practices that aid mitigation and adaptation to climate change and at the same time enhance production. Researches and a corresponding creation of awareness on the most efficient and environmentally safe way of using practices that contribute to climate change should be intensified, since the pressure on ensuring food security remains a formidable challenge in the nation.
\end{abstract}

Key words: soil conservation, climate change, farmer, potential, threat.

\section{Introduction}

Achieving food security in its totality continues to be a challenge not only to developing nations but also to the developed world (Angela, nd). According to FAO (2006) an estimated 854 million people worldwide are still undernourished and almost $33 \%$ or close to 200 million people in Africa are chronically undernourished. The situation in Sub-Saharan Africa is particularly dire with the number of hungry people increasing by 20 percent since 1990 (Braun, 2005). In Nigeria the situation is not different. Kumolu (2010) reported that about 40 million people in Nigeria are believed to be hungry and a large percentage of the population lack access to adequate food. 


\section{Journal of Agricultural Extension}

Vol. 17 (1) June, 2013

ISSN 1119-944X

Land degradation is one of the biggest threats to sustainable development of agriculture, food security and poverty reduction in the world and Nigeria in particular. According to Barbier, (2003), land degradation is the result of a combination of social, economic, cultural, political and biophysical forces operating across a broad spectrum of temporal and spatial scales but essentially arises from bad land management that encourages soil erosion by wind and water, bad irrigation management leading to salinization, excessive use of fertilizer that leads to soil acidification and formation of acid sulfate soil resulting in barren soil, over grazing of rangeland and more widely and insidiously through loss of soil organic matter and loss of biodiversity.

World Watch (2012) reports that according to a study conducted for the International Food Policy Research Institute, each year an estimated 10 million hectares of cropland worldwide are abandoned due to soil erosion and diminished production caused by erosion. Another 10 million hectares are critically damaged each year by salinization, in large part as a result of irrigation and/or improper drainage methods. This loss amounts to more than 1.3 percent of total cropland annually. Primarily, farmers depend on rich topsoil for production of crops but about 1.9 billion tons of topsoil washes or blows away each year with 1.3 billion tons of excessive erosion (www.planetwire.org/files.fcgi/291.agricult.pdf). Consequently, most of the additional cropland needed to replace yearly losses comes from the world's forest areas.

According to World Bank report of 1990, the long term loss to Nigeria from environmental degradation was estimated to be about $\$ 5$ million annually (Ezeaku, 2012). With gully erosion widespread in southern Nigeria, the federal government spent almost 91.0 billion naira on the periodic rehabilitation aid and replacement project of the Bar Beach in Lagos (UNCSD, 1997) .World Bank reported that in 1990, gullies occupied $4 \%$ of the land area of Anambra, Imo, Abia, and Enugu States. Ogbonna, Onyenweaku and Mbanasor (2007) remarked that the situation of soil degradation that requires immediate soil conservation attention is more precarious in the southeastern states of Nigeria especially in Enugu State. Therefore, use of sustainable soil conservation techniques is of paramount importance to achieving increased production and food security of the country.

Soil conservation according to Ezeaku (2012) is a set of management strategies for prevention of soil being eroded from the earth's surface or becoming chemically altered by over use, salinization, acidification, or other chemical soil contamination. It comprises the combination of all methods of management and land use to guard against soil depletion or deterioration by natural or man-induced factors. In the opinion of Dumaski, Peiretti, Benitis, McCarry et. al., (2006), soil conservation efforts of farmers promote minimum disturbance of the soil by tillage, balance application of chemical inputs which are only required for improved soil quality for healthy crop and animal production with careful management. Thus, effective soil conservation practices reduce land and water pollution; reduce long-term dependency on external inputs which often times led to increased cost of production, enhance environmental management, improved water quality and water use efficiency, reduced emission of green house gases through lessened use of fossil fuel and finally improved agricultural productivity with minimum cost (Smith and Smithers, 2006). 


\section{Journal of Agricultural Extension}

Vol. 17 (1) June, 2013

ISSN 1119-944X

Traditionally, farmers employ several soil conservation practices ranging from simple agronomic practices, soil management and use of mechanical methods of soil management. Though the use of these practices has considerably sustained production at least on subsistence level, but their impacts (long and short term) in relation to adapting, mitigating or exacerbating the problems of climate variability should be of concern. It is generally believed that agriculture ranks high as one of the major contributors to climate change and a sector most vulnerable to climate change (IPCC, 2007). Organic Agriculture Association (2008) states that agricultural land use is responsible for approximately $15 \%$ of all green house gas (GHG) emission. Specifically, agricultural processes comprise of $54 \%$ of methane emissions, roughly $80 \%$ of nitrous oxide emission, and virtually all carbon dioxide emissions tied to land use (Niggli, Fliessbach, and Hepperly, 2008). On another hand, agriculture stands as the most vulnerable sector because of its heavy reliance on sustainable use of natural resources. Another paradox is the notion that it has potential for mitigating to climate change. This calls for a rethinking on the current soil conservation practices employed by farmers for agricultural production. Therefore examining the current soil conservation practices employed by arable crop farmers in relation to climate change phenomenon is an imperative .The study aimed to;

* ascertain and examine soil conservation practices used by famers;

* examine farmers' preference of soil conservation practices and reasons for the preference; and

* identify constraints to the use of soil conservation practices.

\section{Methodology}

The study was conducted in Enugu - North Agricultural Zone of Enugu State, Nigeria. Enugu North Agricultural Zone consists of eight (8) blocks which includes: Nsukka 1, Nsukka II, Igbo-Eze I, Igbo-Eze II, Udenu, Igbo-Etiti, Uzo-Uwani I, and Uzo-Uwani II. Arable crop farmers in the zone constituted the population. Multistage random selection technique was used. The first stage involved random selection of six blocks from the zone by simple random technique. The second stage was the selection of two cells from each block using simple random selection techniques, giving a total of twelve cells for the study. Lastly, ten arable crop farmers were selected from list of arable crop farmers provided by extension agents using simple random selection technique. A total sample size of 120 respondents was used. Data were collected by the use of structured interview schedule. Respondents were asked to indicate the methods of soil conservation employed in the farm (example mulching, planting of cover crops, conservation-tillage crop rotation, organic manures, inorganic manure and others), their preference and reasons for preference of soil conservation used. The respondents indicated their preference on a four point Likert type scale of highly preferred (4), preferred (3), less preferred (2), and least preferred (1). Respondents were also asked to indicate among listed variables, problems encountered while using a particular soil conservation practice. Data collected were analyzed using descriptive statistics. (frequency distribution, percentage, mean and standard deviation). Preference was determined using the mean cut off point $\geq 2.5$ as most preferred and $<2.5$ as less preferred. 


\section{Results and Discussion}

\section{Soil conservation practices used}

Table 1 shows that respondents employed organic manure (87.5\%), cover crops $(87.5 \%)$, crop rotation $(86.7 \%)$, mulching $(85.8 \%)$, inorganic manure $(76.7 \%)$, and terracing $(60.8 \%)$ to conserve the soil. Only $30 \%$ and $0.8 \%$ of the respondents practiced planting of windbreak and conservation-tillage in their farms, respectively. Generally, respondents used both agronomic, soil management and mechanical strategies of soil conservation. Either practices are important because they variously affect chemical, physical and boilogical properties of soil. For instance, agronomic soil conservation practices(cover crops, mulching,crop rotatio, fallowing and others ) use the effect of surface covers to reduce erosion by water and wind in order to conserve the soil, protect the soil from direct sun rays and enrich soil by the decay of their fallen leaves (Olaitan and Omamia, 2006) and some reduces the risk of serious pest and disease outbreaks. Also highlighting on its importance, Agele, Iremiren, and Ojeniye ( 2000 ) pointed out that the crop residues released reduce the soil temperature by some degree in the upper centimetes of the top soil and priovide better moisture conservation by reducing the intensity of radiation, wind velocity and evaporartion. It is these attributes that enhanced its potential for climate change adaptation and mitigation. Infact, Enete, Madu, Onwubuya, Onyekuru et al. (2011) identified some of the practices as indigenous adaptation practices used by farmers in south east Nigeria. It boosts adaptation to erosion, effect of direct sun rays on the soil, increase pest and diseases, loss of soil biomass and reduce soil fertility associated with climate change. The mitigation potential is provided by its ability to significantly contribute to soil carbon sequestration (carbon uptake from the atmosphere) through increase organic matter content of the soil.

In the same manner, soil management practices which include conservation tillage, the use of organic and inorganic manure holds great potentials for climate change adaptation and mitigation. Specifically, conservation tillage (zero tillage, minimium tillage, ridge tillage etc.) particularly zero tillage mitigate against release of $\mathrm{CO}_{2}$ and $\mathrm{N}_{2} \mathrm{O}$ caused by intensive tillage and burning of fossil fuel. It only becomes a threat where farmers use slash and burn for zero tillage. Similarly, the use of inorganic (fertilizer) and organic manure(animal dung/droppings) increases vulnerability (threat) by release of nitrous oxide and methane into the atmosphere. According to Organic consumer Association (2008) they are the two main sources of nitrous oxide. Nevertheless, these soil conservation practices are highly recommended by climate change scholars with emphansis on appropiate management that depend less on use of inorganic manure and that enhance mitigation against release of nitrous oxide. (Ozor, Madukwe, Onokala, Enete et al., 2010; and Nzeh and Eboh , 2011)

Mechanical soil conservation practices namely the use of terrace, vegetative barriers/planting for wind break, contour bonds etc. are not very popular among the farmers. According to Junge, Deji Abaidoo, et al. (2009) they are effective soil conservation technologies as they reduce soil loss, but because the installation and maintenace is usually labour intensive, they are not likely to be adopted by farmers. However, they are both adaptive and mitigation measures to climate variability. When used, exessive soil and wind erosion, loss of degraded lands, and silting up of the field are reduced. The mitigation potentials are achieved through carbon 
sequestration (absorption of carbon from the atmosphere) by tree planting or vegetative barrier.

Table 1

Precentage distribution of repondents by soil conservation practices used

\begin{tabular}{ll}
\hline Conservation practices & $\%$ \\
\hline conservation tillage & $0 . .8$ \\
Organic manure & 87.7 \\
Mulching & 85.8 \\
Inorganic manure & 76.7 \\
Planting cover crops & 87.5 \\
Crop rotation & 86.7 \\
Contours bonds & 85.8 \\
Terracing & 60.8 \\
Planting windbreak & 30.0 \\
\hline Multiple response &
\end{tabular}

\section{Preferences of soil conservation practices}

The mean scores in Table 2 show that organic manure $(M=3.32 ; S . D=1.13)$, inorganic manure $(M=3.08$; $S . D=1.16)$, Planting of cover crops $(M=3.05 ; S . D=$ 1.15) and mulching $(M=2.82 ; S . D=1.08)$ were the most preferred soil conservative practices. The less preferred soil conservative practices included terracing $(M=2.39$; $S . D=1.37)$, Contour bond $(M=1.88 ; S . D=1.18)$, planting windbreak $(M=1.68 ; S . D=$ $0.74)$, and conservation tillage $(M=1.39 ; S . D=0.82)$. The high standard deviation of responses of the most preferred practices portrays varying opinion and probably the frequency of use by the respondents. Respondents are more homogenous in the perception of less preferred conservation practices and this suggests that these practices are yet to be welcomed and adopted as one of the effective soil conservation practices, perhaps due to location specificity of some of the practices. The integration of these practices especially in erosion prone areas is expedient in the present reality of climate change and the call for effective adaptation and mitigation measures. However, respondents' reasons for the preference are discuss as follows:

Table 2

Mean score based on respondents' preference of the soil conservation practices

\begin{tabular}{lll}
\hline Variable & Mean & S.D \\
\hline conservation tillage & 1.39 & 0.82 \\
Organic manure & $3.32^{*}$ & 1.13 \\
Mulching & $2.82^{*}$ & 1.08 \\
Inorganic manure & $3.08^{*}$ & 1.16 \\
Planting cover crops & $3.05^{\star}$ & 1.15 \\
Crop rotation & $2.86^{*}$ & 1.42 \\
Contours bonds & 1.88 & 1.18 \\
Terracing & 2.39 & 1.37 \\
Planting windbreak & 1.68 & 0.74 \\
\hline
\end{tabular}

*Most preferred soil conservative practices 


\section{Reasons for using soil conservation practices Conservation tillage}

Table 3 shows that respondents used conservation tillage' because it reduces production cost $(50.4 \%)$, is less labour intensive $(20.9 \%)$, and that it is less expensive (19.4\%). About $11 \%, 8 \%$, and $6 \%$ stated that it has no environmental pollution, it is easily accessible, conserve soil moisture and controls erosions, respectively. The results show that reduced cost of production is the major factor influencing use of conservation-tillage. The respondents seem to be unaware of other benefits. For example Nalewaje, (2001) reported that avoiding tillage averts disruption of soil aggregate, protect soil organic matter from accelerated decomposition and restore several soil biological processes. Above all, it is an emergent crop production technique which can increase the amount of water in the soil and decrease erosion. Thus, Bellarlly, Foereid, Hasting and Smith (2008) and Niggli, Fliessbach and Hepperly. (2008) identified it as one of the sustainable agricultural practices beneficial to reducing the effect of climate change.

\section{Organic manure}

The respondents preferred organic manure because it enhances productivity $(90.7 \%)$, high quality products $(83.7 \%)$, long term nutrient value $(80.6 \%)$, increase water filtration $(72.1 \%)$, availability and accessibility $(64.3 \%)$, increase soil biological activities (59.7\%), aid soil aeration (57.4\%), and control erosion (55.9\%) (Table 3 ). Other reasons include less environmental pollution (48.1\%), conserve soil moisture $(45.0 \%)$ and less expensive $(45.0 \%)$. This is in agreement with the conservation properties of organic manure. Hence, it's importance for carbon sequestration and improvement of ecosystem resilience. However, appropriate management particularly during fermentation and/or when animal waste comes in contact with water and slurry (decomposition) is necessary to reduce potential threats to the climate.

\section{Mulching}

Table 3 shows that the respondents practiced mulching because it reduces the effect of heat from the sun $(87.6 \%)$, conserve soil moisture $(86.8 \%)$, has no environmental pollution $(63.6 \%)$, and enhances productivity $(53.5 \%)$, while $48.8 \%$, $37.2 \%, 31.8 \%$ and $30.2 \%$ practiced mulching because of ease of accessibility, less expensive, increase soil microbial activities and increases water infiltration, respectively. This agrees with FAO (2006) that mulching protects against erosion, suppresses weeds, increase water infiltration and promotes soil biological activities. Also crop residues reduces the soil temperature by some degrees in the upper centimeters of the topsoil and provide better moisture conservation by reducing the intensity of radiation, wind velocity, and evaporation (Agele, et al., 2000). These characteristics effect of mulching constitute its potential for adaptation to climate change indicators such as increased temperature, erosion etc. 


\section{Journal of Agricultural Extension}

Vol. 17 (1) June, 2013

ISSN 1119-944X

\section{Inorganic manure}

Majority (86.8\%) of the respondents used inorganic manure because it enhances productivity, while $55.8 \%$ and $55.0 \%$, used it for higher quality product and long term nutrient values; respectively (Table 3 ). Other reasons namely less labour intensive (18.6\%), accessibility and availability (16.3\%), aid aeration (14.0\%), others were lowly perceived as reasons for use of inorganic manure. The result revealed that economic benefit is the key driver for application of inorganic soil conservation practice. The low perception of other reasons seem to suggest that the respondents are aware of its limitation in engendering long term improved physical, chemical and biological property of the soil. Frequent use of inorganic manure (fertilizer) has been associated with land degradation, increase in soil acidification and the formation of acid sulfate soil resulting in barren soil which eventually leads to decrease in agricultural productivity ( Barbier, 2003)). Above all, the doubling of green house gas (GHGs) production during the last 35 years was associated with a 6.9 fold increase in nitrogen fertilizer, a 3.5 fold increase in phosphorus fertilizer and a 1.7 fold increase in irrigated land (FAO, 2008). This makes it a threat instead of resource in adapting or mitigating climate change, especially where application is highly intensive.

\section{Cover crop}

Table 3 shows that (89.9\%) of the respondents practiced cover cropping because it supresses weeds $(89.9 \%)$, conserves soil moisture $(86.0 \%)$, reduces heat from the sun $(84.5 \%)$, and had no environmental pollution $(53.5 \%)$, A significant proportion used it for enhanced productivity $(45.0 \%)$, control erosion $(45.0 \%)$, aid soil aeration $(39.5 \%)$, increases soil biological activities (34.9\%) and increases water infiltration $(31,0 \%)$. Relatively, the reasons are in line with FAO (2006) which maintained that permanent soil cover protects against erosion, suppresses weeds, increase water infiltration and promotes soil biological activities. This is further substantiated by Olaitan and Omomia (2006) who stated that cover crops are mainly planted to protect the soil from direct sun rays, reduce erosion, and enrich the soil by the decay of fallen leaves. These attributes makes it potentially a resource for both adaptation and mitigation against climate variability and global warming.

\section{Crop rotation}

The respondents indicated that the reasons for practicing crop rotation were to enhance production (79.1\%), had no environmental pollution $(72.9 \%)$, gives higher qaulity products (65.9\%), and control erosion (60.5\%) (Table 3$)$. About $46 \%, 43 \%$, and $21 \%$ applied crop rotation because it increases water infiltration, conserve soil moisture and it is less expensive, respectively. Characteristically, soil rotation reduces the risk of serious pest and disease outbreak, check erosion, improve soil fertility, and balance nutrient removal from the soil among others. In this way it increases resilience and reduces vulnerablity of production system to climate change. 


\section{Contour bond}

Majority $(59.7 \%)$ of the respondents practiced contour bond because it enhanced productivity, while $44.2 \%, 38.0 \%$ and $30.2 \%$ indicated that it has no environmental pollution, contols erosion and conserves soil moisture, respectively(Table 3). A lesser proportion (22.5\%) used it to increase water infiltration. Other reasons indicated by the respondents were because contour bond is less expensive $(10.9 \%)$, availabilty/accessibilty (10.9\%), give higher quality products $(9.3 \%)$ and others The low perception expressed over resason for use confirms low preference and use of contour bond as indicated in the previous results. It could be that the respondents either have constraints to its use or they are not very knowledgeable of its application/benefits. Unfortunately it is supposed to be a common erosion control measure particularly in erosion prone areas. Thus, it is relevant for adaptation to climate associated problems like erosion.

\section{Terracing}

The respondents indicated that terracing was practiced in their farm to enhance productivity $(39.5 \%)$, control erosion $(29.5 \%)$, conserve soil moisture $(26.4 \%)$, has no environmental pollution (24.0\%), and increases water infiltration (21.7\%) (Table 3). Relatively, the reasons expressed agree with Conservation Technology Information (2002) report that terrace prevent gully erosion and decrease sediment pollution in water. However, the perception of the respondents suggests that use of terracing for soil conservation is not a common practice. This is not surprising because according to Igbokwe (1996) high labor intensity, time- consuming regular inspection, high consumption of scarce farmland, and the large amounts of construction material required stop farmers from installing or maintaining terracing. Nevertheless, it is important for adapting to changes caused by climate variability (erosion).

\section{Planting of Wind break}

Table 3 shows that respondents plant Windbreak because it controls erosion $(67.4 \%)$, reduce the effect of heat from the sun $(44.2 \%)$, suppresses weeds $(41.9 \%)$ and has no environmental pollution (39.5\%). Other reasons for planting windbreak include; it enhanced productivity (23.3\%), increase water infiltration (12.5\%), and others. This is true of tree planting but it is surprising that is still not a common practice among farmers. Rather indiscriminate felling of trees seems to be more widespread in communities. Planting of trees in farms, and surroundings is essential for adaptation (against heat from sun, wind erosion etc) and mitigation (carbon sequestration and ecosystem resilience) 
Table 3

Percentage distribution of respondents by reasons for preference of soil conservation practices

\begin{tabular}{|c|c|c|c|c|c|c|c|c|c|}
\hline 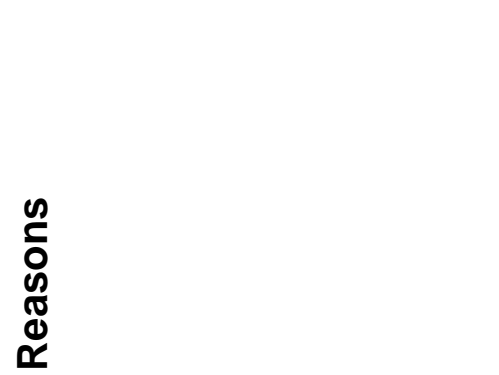 & 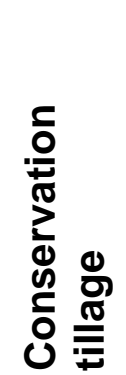 & 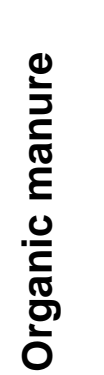 & 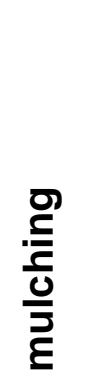 & 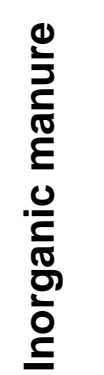 & $\begin{array}{l}\text { 응 } \\
\frac{0}{0} \\
\frac{1}{0} \\
0 \\
0\end{array}$ & $\begin{array}{l}\mathscr{0} \\
\stackrel{0}{0} \\
\stackrel{0}{\pi} \\
\stackrel{\pi}{0} \\
\frac{1}{0} \\
\stackrel{0}{0} \\
\stackrel{0}{0}\end{array}$ & 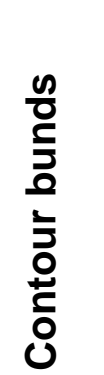 & 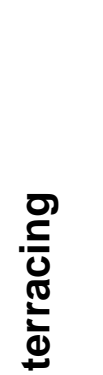 & 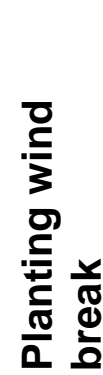 \\
\hline Less expensive & 19.5 & 45.0 & 37.2 & 8.5 & 9.3 & 20.9 & 10.9 & 3.9 & 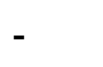 \\
\hline Availability/accessibility & 7.8 & 64.3 & 48.8 & 16.3 & 8.5 & 5.4 & 10.9 & 10.9 & 3.1 \\
\hline Long term nutrient value & - & 80.6 & 6.2 & 55.0 & 7.8 & 8.5 & - & - & - \\
\hline Aid soil aeration & - & 57.4 & 14.0 & 14.0 & 39.5 & 7.0 & - & 10.9 & - \\
\hline conserve moisture & 6.2 & 45.0 & 86.8 & 6.2 & 86.0 & 43.4 & 30.2 & 26.4 & 9.3 \\
\hline higher quality product & - & 83.7 & 5.4 & 55.8 & 16.3 & 65.9 & 9.3 & 18.6 & - \\
\hline Less labour intensive & - & 8.5 & 4.7 & 18.6 & 8.5 & 2.3 & 2.3 & - & - \\
\hline $\begin{array}{l}\text { Has no environmental } \\
\text { pollution }\end{array}$ & 10.9 & 48.1 & 63.3 & 11.6 & 53.5 & 72.9 & 44.2 & 24.0 & 39.5 \\
\hline Increase water infilteration & - & 72.1 & 30.2 & 5.4 & 31.0 & 45.7 & 22.5 & 21.7 & 12.5 \\
\hline $\begin{array}{l}\text { Increase soil biological } \\
\text { activities }\end{array}$ & - & 59.7 & 31.8 & 8.5 & 34.9 & 5.4 & - & - & - \\
\hline Control erosion & 6.2 & 55.8 & 17.1 & 7.0 & 45.0 & 60.5 & 38.0 & 29.5 & 67.4 \\
\hline Reduce effect of heat & - & 6.2 & 87.6 & 7.0 & 84.5 & 3.9 & - & - & 44.2 \\
\hline Suppress weeds & - & 2.3 & 24.0 & 2.3 & 89.9 & 8.5 & - & 7.8 & 41.9 \\
\hline Reduce production cost & 50.4 & 14.0 & 13.3 & 1.6 & 8.5 & 9.3 & 3.9 & 7.0 & - \\
\hline Enhanced productivity & - & 90.7 & 53.5 & 86.8 & 45.0 & 79.1 & 59.7 & 39.5 & 23.3 \\
\hline
\end{tabular}

\section{Multiple response}

\section{Constraints to use of soil conservation practices Conservation tillage}

Results show that use of soil conservation practices are constrained by several factors. Majority (70.8\%) of the respondents perceived that conservation tillage method encourages weed growth, while $15.0 \%$ and $10.0 \%$ indicated that it increases pest infestation and inhibibits soil microbial activities (Table 4). Similarly, greater proportion $(55.8 \%, 41.7 \%$ and $40.8 \%$ ) of the respondents perceived that bulkiness of material, encouragement of weed growth and environmental pollution limit the use of organic manure for soil conservation, respectively. Other constraints perceived by the farmers were that organic manure increases pest infestation (32.5\%), high cost of material $(21.7 \%)$, requires multiple applications $(20.8 \%)$, inadequate capital (16.7\%) and others. Also use of inorganic manure was largely constrained by inaccessibility (87.5\%), inadequate capital $(79.2 \%)$, high cost of material (68.3\%), unavailability $(62.5 \%)$, multiple application $(49.2 \%)$, causes environmental pollution (41.7\%) and others, while inadequate capital (53.3\%), and 


\section{Journal of Agricultural Extension}

Vol. 17 (1) June, 2013

ISSN 1119-944X

size of farm land (23\%) were identified as major limiting factors to use of crop rotation for soil conservation.

Furthermore, Table 4 shows that high labour involvement constrained use of cover crops (51.7\%), contour bonds (62.5\%), and terracing (39.2\%). About $52 \%$ and $42 \%$ of the respondents expressed that bulky nature of material and poor access constrained use of mulching as soil conservation practice. Only $30.0 \%$ of the respondents perceived that planting windbreaks constitute nuisance during cultivation. Largely concern on the cost of use is more outstanding as constraint than environmental issues related to application of some practices. The perceptions suggest that while some practices have gained popularity (inorganic manure, organic manure etc.), others like planting of wind break, crop rotation, contour bonds and others are less commonly used. Unfortunately, some of these practices constitute adaptation/mitigation measures recommended against climate-related land degradation and problems. (FAO, 2008 and Ozor, Madukwe, Onokala, 2010). Above all, lack of information, knowledge of application and benefits; and location specificity that characterized some soil conservation practices may have influenced the low perception of the constraints.

Table 4

Percentage distribution of respondents by constraints to use of soil conservation practices

\begin{tabular}{|c|c|c|c|c|c|c|c|c|c|}
\hline 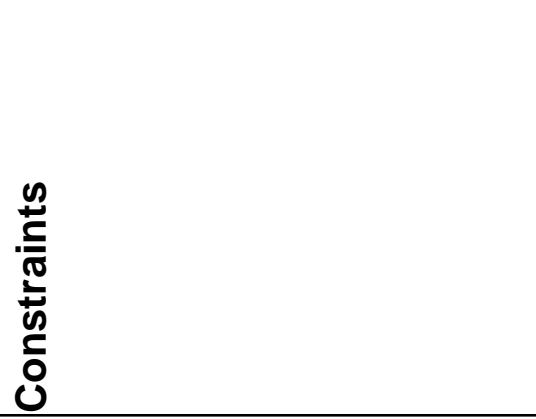 & 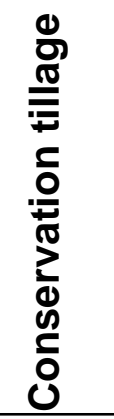 & 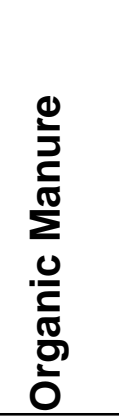 & 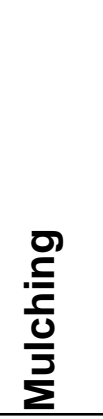 & 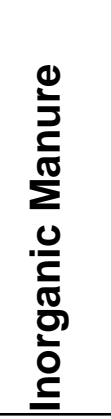 & 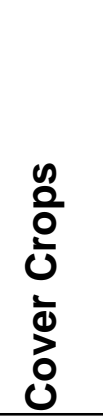 & $\begin{array}{l}\frac{1}{0} \\
\frac{0}{\pi} \\
\frac{\pi}{0} \\
\frac{0}{0} \\
\frac{0}{0}\end{array}$ & 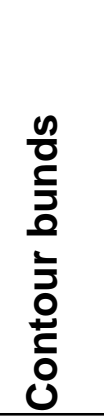 & 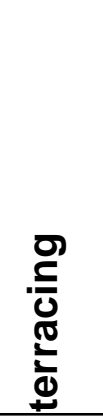 & 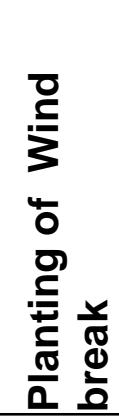 \\
\hline Increase pest infection & 15.0 & 32.5 & - & 11.7 & - & 0.8 & - & - & 20.8 \\
\hline Inadequate capital & 2.5 & 16.7 & 14.2 & 79.2 & 11.7 & 53.3 & - & - & \\
\hline $\begin{array}{l}\text { Unavailability of raw } \\
\text { material }\end{array}$ & - & 17.5 & 15.0 & 62.5 & - & - & - & - & 15.8 \\
\hline High cost of material & - & 21.3 & 14.2 & 68.3 & - & - & - & - & - \\
\hline Environmental pollution & - & 40.8 & & 41.7 & - & - & - & & - \\
\hline Bully nature of material & - & 55.8 & 51.7 & 9.2 & - & - & - & & - \\
\hline Encourage weed growth & 70.8 & 41.7 & 15.8 & 20.8 & - & - & - & & - \\
\hline Require multiple application & - & 20.8 & - & 49.2 & - & - & - & - & - \\
\hline $\begin{array}{l}\text { Delay/ inhibits microbial } \\
\text { activities }\end{array}$ & 3.3 & - & 6.7 & - & - & - & - & & \\
\hline High labour involvement & - & - & 26.7 & 17.5 & 51.7 & - & 62.5 & 39.2 & 10.0 \\
\hline Not accessible on time & - & - & 41.7 & 87.5 & - & - & - & - & - \\
\hline Reduction in soil fertility & 6.7 & - & - & - & - & - & - & - & - \\
\hline $\begin{array}{l}\text { In adequate size of farm } \\
\text { land }\end{array}$ & - & - & - & - & - & 23.3 & 19.2 & 15.0 & - \\
\hline $\begin{array}{l}\text { Constitute nuisance to } \\
\text { planting }\end{array}$ & - & - & - & - & - & - & - & - & 30.0 \\
\hline
\end{tabular}

Multiple response 


\section{Journal of Agricultural Extension}

Vol. 17 (1) June, 2013

ISSN 1119-944X

\section{Conclusion}

The study shows that arable crop farmers used different soil conservation practices namely conservation tillage, organic manure, inorganic manure, mulching, use of cover crops, crop rotation, coutour bond, and others. However, the respondents preferred organic manure, planting of cover crops, inorganic manure, and mulching. Economic benefits in terms of the cost,labour, timely access, and productivity were central to the reason for prefernce of the practices. Relatively the respondents were less concern about the environmental implications and long term impact on the soil. Overall, because of the chemical, biological and physical effect on the soil, most of the practices hold great potential for adaptation and mitigation to climate change execpt the use of inorganic manure which characteristically exacerbates the problem of climate change and increases vulnerability of production system.

On another hand some of the practices which hitherto provide adaptation/mitigation benefits, example use of organic manure could aid climate change especially when it is not appropiately managed. Above all the use of these practices are constrained by several factors such as cost, logistics, and others The study therefore recommends that extension and stakeholders should intensify efforts on creation of awareness on climate change in farming communities and re-orientate farmers on climate implications of the soil consevation practices used. Farmers should be trained and encouraged to increase dependance on practices that present high potentials for adaptation/mitigation to climate change. Regulatory measures should be put in place to regulate use of some of the practices such as inorganic manure which are detrimental to climate, increase vulnerability and reduce resilience of farming system and communities. Researches and training on the best management practices for soil conservation that has dual effects on the climate is expedient.

\section{Reference}

Agele, S. O, Iremiren, G.O and Ojeniye, S.O. (2000). Effects of tillage and mulching on the growth, development and yield of late-season tomato (Lycopersicon esculentum L.) in the Humid South of Nigeria. Journal of Agricultural Science, 134, pp.55-59.

Angela Mwaniki (nd) Achieving food security in Africa: Challenges and issues. Retrieved from htt:///www.un.org/Africa/osaaa/reports on $7^{\text {th }}$ March, 2012

Barbier, E.B. (2003). The economics of soil erosion: Theory, methodology and examples. Paper Presented to the Fifth Biannual Workshop on Economy and Environment in Southeast Asia, Singapore, November $28^{\text {th }}-30^{\text {th }}$.

Bellarby, J., Foereid, B. and Smith, A. (2008). Cool farming: Climate Impact of Agriculture and Mitigation Potential. Amsterdam, Greenpeace International.

Braun, Joachim Von (2005). The world food situation: An overview. IFPRI , CGIAR Annual General Meeting, Marrakech, Morocco, December $6^{\text {th }}$, pp. 1-4 


\section{Journal of Agricultural Extension}

Vol. 17 (1) June, 2013

ISSN 1119-944X

Dumanski, J., Peiretti, J., Benitis, R.,McGary, D. and Pieri, C. (2006). The Paradigm of Conservation Tillage. Proceedings of World Association of Soil and Water Conservation, pp. $58-64$

Enete, A. A., Madu, I. I., Onwubuya, E. A. Onyekulu, A. A., Mojekwu, J. C., and Eze, F. (2011). Indigenous agricultural adaptation to climate change: Study of Southeast Nigeria. African Technology Policy Studies NetworkTECHNOPOLICY BRIEF NO.25, Retrieved from www.atpsnet.org.

Ezeaku, P. I. (2012) Soil conservation and management options for adaptation to climate change in the $21^{\text {st }}$ century In: A. I., Enete, . and M. I. Uguru (eds) Critical Issues in Agricultural Adaptation to Climate Change in Nigeria,. Enugu, Chengo limited, pp.84-113

Food and Agriculture Organization (FAO) (2008). Organic Agriculture and climate change. Retrieved from htt://www.fao.org/DOCREP/005/Y4137e02b.htm\#89 on $10^{\text {th }}$ August 2010.

Food and Agriculture Organization of the United Nations (FAO) (2006). Undernourished people worldwide. Retreieved from www.ifad.org/thermatic/rural/rural2htm on $6^{\text {th }}$ August 2010

Igbokwe, E. M. (1996) A soil and water conservation system under threat.: A visit to Maku, Nigeria. In: I. R. Scoones and I. C. Toulmin. (eds) Sustaining the Soil Indigenous soil and Water Conservation in Africa, London, Earthscan Publication, pp. 219-243.

Intergovernmental Panel on Climate Change (IPCC) (2007). Climate change 2007: Sythesis Report. Contribution of working groups1, 11 and 111 to the fourth assessment report of the Intergovernmental Panel Climate Change, Geneva, Switzerland.

Junge, B., Deji, O., Abaidoo, R., Chikoye, C. Stahr, K. (2009). Farmers' adoption of soil conservation technologies: A case study from Osun State, Nigeria. The Journal of Agricultural Education and Extension, Vol. 15(3), pp. 257-274.

Kumolu, C. (2010) Nigeria: Food security experts make case for urgent actions on small scale farming. Retrieved from http://.vanguardngr.com/ on $29^{\text {th }}$ April 2010.

Mbagwu, G. S. (1995). Low-cost methods for the control of soil erosion on farmers plots. Paper presented at Monthly Technology Review Meeting (MTRM) of Borno State Agricultural Development Programme, Maiduguri, June $6^{\text {th }}$.

Niggli, U., Fliesssbach, A and Hepperly, P. (2008). Low green house gas agriculure, mitigation and adaptation potential of sustainable farming systems. Rome. FAO.

Nzeh, E. C. and Eboh, E. C. (2011). Technological challenges of climate change adaptation in Nigeria: Insight from Enugu State. African Technology Policy 
Studies Network. TECHNOPOLCYBRIEF, 24. Retrieved from www. atpsnet.org.

Ogbonna, M. C; Onyenweaku, C. E. and Mbanasor, J. A. (2007) Economics of soil conservation farming techniques in Abia State, Nigeria. International Journal of Agriculture and Rural Development, Vol. 7 (2), pp. 62-66.

Olaitan, S.O and Omomia, O. A. (2006). Round-up Agricultural Science; A Complete Guide. Lagos: Longman Nigerian PLC.

Organic Consumer Association (2008). Organic agriculture can help stabilize climate change.

http://www.orgicconsumers.org/organic/stabalize062404.cfm on $10^{\text {th }}$ August $\underline{2010}$

Ozor, N., Madukwe, M. C., Onokala, P. C., Enete, A., Garforth, C. J. Eboh, E. C., Ujah, O., Amaechina, E. (2010). A framework for agricultural adaptation to climate change in southern Nigeria. Development Partnership in Higher Education DeIPHE 326 Project Executive Summary.

Smith, B. and Smithers, J. (2006). Adoption of Soil Conservation Practices: An empirical analysis in Ontario, Canada. Land Degradation and Rehabilitation, 3, pp. 1-14.

United Commission on Sustainable Development Report (UNCSD) (1997). Fifth Session $7^{\text {th }}-25^{\text {th }}$ April New York. Retrieved from http://www.un.org/dpcsd/earthsummit

www.planetwire.org/files.fcgi/291.agricult.pdf Retrieved 8th march, 2012 